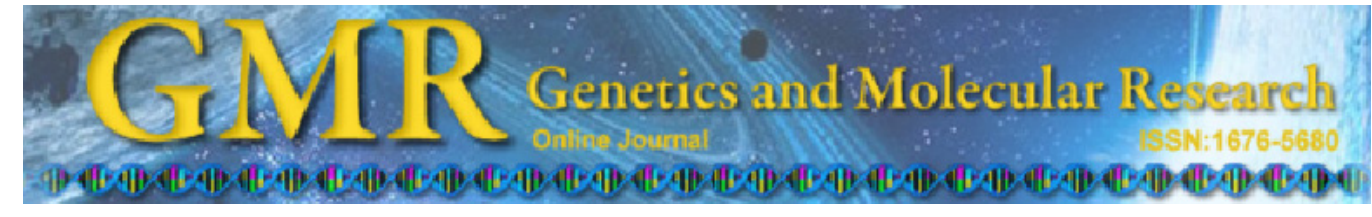

\title{
Microsatellite analysis as a tool for discriminating an interfamily hybrid between olive flounder and starry flounder
}

\author{
J.-H. Kang', Y.-K. Kim¹, J.-Y. Park' ${ }^{1}$, C.-M. An ${ }^{1}$, M.-M. Nam², S.G. Byun², \\ B.I. Lee ${ }^{2}$, J.H. Lee ${ }^{2}$ and T.-J. Choi ${ }^{3}$ \\ ${ }^{1}$ Biotechnology Research Division, Busan, Korea \\ ${ }^{2}$ East Sea Fisheries Research Institute, Uljin, Korea \\ ${ }^{3}$ Department of Microbiology, Pukyong National University, Busan, Korea
}

Corresponding author: T.-J. Choi

E-mail: choitj@pknu.ac.kr

Genet. Mol. Res. 10 (4): 2786-2794 (2011)

Received May 30, 2011

Accepted September 7, 2011

Published October 31, 2011

DOI http://dx.doi.org/10.4238/2011.October.31.16

\begin{abstract}
An interspecific artificial hybrid was produced between two economically important aquaculture flatfish: olive flounder (Paralichthys olivaceus) and starry flounder (P. stellatus). This hybrid displays the rapid growth characteristic of the former and tolerance to low temperatures and low salinity of the latter, but the genetics of inheritance in this hybrid have not been elucidated. Polymorphic microsatellite markers developed for $P$. olivaceus and $P$. stellatus were tested to determine if these markers can be used for analysis of parentage and genetic inheritance. Multiplex PCR using two primer sets that were specific to each species produced PCR products of different sizes; these could be used for the identification of interspecific hybrids. Among the 192 primers derived from olive flounder, $25.5 \%$ of the primer sets successfully amplified genomic DNA from starry flounder, and $23 \%$ of the 56 primer sets originating from starry flounder amplified DNA from olive flounder. Analysis of genetic inheritance in the hybrid using seven of the 62 microsatellite markers common to both species demonstrated classic Mendelian inheritance of these markers in the hybrid progeny, with the exception of one locus identified as a null allele in the hybrid.
\end{abstract}


These results demonstrate that cross-specific microsatellite markers can be used tools for parentage analysis of hybrid flatfish, for mapping quantitative trait loci, for marker-assisted selective breeding, and for studies of the evolution of fish.

Key words: Hybrid; Microsatellite; Olive flounder; Starry flounder

\section{INTRODUCTION}

Hybridization is more common in fish than in any other vertebrate because of their external fertilization and similar mating behaviors (Leary et al., 1995). In addition to hybridization in natural ecosystems, usually between native and nonnative taxa, artificially induced hybridization has been employed as a tool to improve aquaculture productivity through heterosis in fish (Moav, 1979; Ihssen et al., 1988; Wohlfarth, 1993).

The olive flounder Paralichthys olivaceus (Temminck and Schlegel) is one of the most important fishery and aquaculture species in Korea, Japan, and China. The starry flounder P. stellatus (Pallas), another flatfish in the same order (Pleuronectiformes), is a native fish in the vicinity of the Korean Peninsula. It has a slow growth rate but high tolerance to low temperatures and low salinity. Therefore, a hybrid between P. olivaceus and P. stellatus was produced to enhance growth and tolerance to environmental stresses. Aquafarming of the hybrid is underway in Korea (Nam et al., 2008). Although the hybrid fish displayed the intended phenotypes, their similar morphology made distinguishing the hybrid progeny from their parents difficult, especially in their early stages.

Several molecular markers such as alloenzymes (Berrebi et al., 2000), mitochondrial DNA (Snoj et al., 2000), microsatellites (Fumagalli et al., 2002), random amplified polymorphic DNA (RAPD; Jug et al., 2004), and single nucleotide polymorphisms (Harwood and Phillips, 2011) have been used for the discrimination of hybrids and parentage analysis in fish. Although each method has advantages and drawbacks in their application, the microsatellite markers are highly useful because they are abundant, evenly distributed, and highly polymorphic. They are also short in length, facilitate genotyping by polymerase chain reaction (PCR) and are codominant markers that allow the generation of maximum genetic information. Polymorphic microsatellite markers have been developed in both P. olivaceus and P. stellatus and have been applied to parentage relationships, monitoring populations, and linkage mapping of these fish (Jarne and Lagoda, 1996; Li et al., 2004; Kang et al., 2008).

In this study, polymorphic microsatellite markers developed for $P$. olivaceus and $P$. stellatus were tested against one another to identify a possible application of these markers in parentage analysis of the hybrid, which would provide valuable information in fish breeding programs and facilitate understanding the molecular dynamics in the hybridization of two fish species from different families.

\section{MATERIAL AND METHODS}

\section{Production of hybrids}

An $\mathrm{F}_{1}$ hybrid family was produced by controlled interspecific hybridization between one female olive flounder and one male starry flounder. The male parent was from wild stock and the female parent was from cultured stock, both collected and maintained at the Uljin 
Hatchery Center, National Fisheries Research \& Development Institute, Korea. The hybrids were raised by running water culture before analysis.

\section{Sample collection and DNA extraction}

A total of 48 progeny ( 6 months of age, average weight of $8.5 \mathrm{~g}$ ) and their two parents were used for the genetic inheritance analysis. Ten of each olive flounder, starry flounder and their hybrid progeny kept at the Uljin Hatchery Center were used for species identification and parentage confirmation of hybrids by multiplex PCR using species-specific primer sets. Small pieces of fin tissue were cut from individuals and preserved in 100\% ethanol. Total DNA was isolated from each sample using a MagExtractor MFX-6100 automated DNA extraction system (Toyobo, Osaka, Japan). The extracted genomic DNA was quantified using a NanoDrop ND-1000 spectrophotometer (Thermo Fisher Scientific, Waltham, MA, USA) and stored at $-20^{\circ} \mathrm{C}$ until microsatellite genotyping analysis.

\section{PCR amplification and genotyping}

In total, 192 olive flounder microsatellite markers used in this study were taken from a previous study for the construction of an olive flounder linkage map (Kang et al., 2008). All 56 microsatellite markers for starry flounder were taken from the GenBank/EMBL/DDBJ database with the prefix Ksf. For multiplex PCR, the 5'-end of each forward primer was labeled with one of three fluorescent dyes: 6-FAM, HEX, or NED (Applied Biosystems, Foster City, CA, USA). PCR for the amplification of microsatellite loci was performed in a $10-\mu \mathrm{L}$ reaction volume containing $1 \mathrm{X}$ ExTaq buffer, 10-50 ng template DNA, $0.2 \mathrm{mM}$ dNTPs, $0.5 \mu \mathrm{M}$ of each primer, and $0.25 \mathrm{U}$ Taq DNA polymerase (Takara, Shiga, Japan), using an RTC 200 thermocycler (MJ Research, Waltham, MA, USA). The PCR conditions were as follows: initial denaturation at $95^{\circ} \mathrm{C}$ for 11 min, followed by 35 cycles of denaturation at $94^{\circ} \mathrm{C}$ for $1 \mathrm{~min}$, annealing at optimum temperature for each primer set for $1 \mathrm{~min}$, and extension at $72^{\circ} \mathrm{C}$ for $1 \mathrm{~min}$, and a final extension at $72^{\circ} \mathrm{C}$ for 5 min. A $1-\mu \mathrm{L}$ aliquot PCR product was mixed with a genotyping reaction mixture containing formamide and a size standard using GeneScan 400HD ROX (Applied Biosystems) and electrophoresed with an ABI 3130 DNA sequencer (Applied Biosystems). The fragment lengths of the PCR products were determined using the GeneMapper ver. 4.0 software (Applied Biosystems). Differences between observed genotypes and Mendelian expectations were assessed using the $\chi^{2}$ test. Multiplex PCR with olive flounder-specific Kop60 marker and starry flounder-specific Ksf5 marker was conducted as above and the PCR product was electrophoresed on a $1.5 \%$ agarose gel.

\section{RESULTS}

\section{Common microsatellite markers}

In total, 248 microsatellite markers, including 192 markers derived from olive flounder and 56 markers from starry flounder, were cross-checked between one another by classical agarose gel electrophoresis. Among the 192 primers derived from olive flounder, 49 (25.5\%) primer sets successfully amplified genomic DNA from starry flounder. Similarly, 13 (23.2\%) of the 56 primer sets originating from starry flounder amplifed DNA from olive flounder. The information for these primers is shown in Table 1. 


\begin{tabular}{|c|c|c|c|c|c|}
\hline Locus & Source & Primer sequence $\left(5^{\prime} \rightarrow 3^{\prime}\right)$ & $\mathrm{Ta}\left({ }^{\circ} \mathrm{C}\right)$ & PCR size (bp) & Accession No. \\
\hline Poli2TUF & Paralichthys olivaceus & $\begin{array}{l}\text { ACAATAGGATGCAGCTGCCT } \\
\text { AAGCGCAAATTGTTATTCCG }\end{array}$ & 62 & $108-126$ & AB037978 \\
\hline Poli11TUF & Paralichthys olivaceus & $\begin{array}{l}\text { ATGAAAACCACCAAGAATCCC } \\
\text { GGCGCATTTGGTAGTTTGTT }\end{array}$ & 62 & $89-132$ & AB037981 \\
\hline Poli18TUF & Paralichthys olivaceus & $\begin{array}{l}\text { CACGCACACACAAGCTCC } \\
\text { CGTGGGGTGAGGTTATGG }\end{array}$ & 65 & $123-147$ & AB037983 \\
\hline Poli29TUF & Paralichthys olivaceus & $\begin{array}{l}\text { AACTCCACAAAAAGCTGATCACAGC } \\
\text { GCCATTCTACAAGCAGCTGCACTAT }\end{array}$ & 65 & $139-147$ & AB037987 \\
\hline Poli38TUF & Paralichthys olivaceus & $\begin{array}{l}\text { CTTACACACAAAGCACAGCCA } \\
\text { CCAGTCTGACATGAAGCGG }\end{array}$ & 65 & $97-132$ & AB459378 \\
\hline Poli105TUF & Paralichthys olivaceus & $\begin{array}{l}\text { TGTCTGTAAATACACCTCCTCTCCCA } \\
\text { TCATCTCCCTGCTCTGACTCAGG }\end{array}$ & 52 & $93-105$ & AB459390 \\
\hline Poli106TUF & Paralichthys olivaceus & $\begin{array}{l}\text { CTGGCTTTTTAAGGAGAGCCACACT } \\
\text { GATCGACCTTGATGAGACTCACAAA }\end{array}$ & 55 & $117-124$ & AB459391 \\
\hline Poli115TUF & Paralichthys olivaceus & $\begin{array}{l}\text { GATGTAGGTCACACACTGAGGCTGA } \\
\text { CCTTTGCATTTGTCTACGCAAGC }\end{array}$ & 62 & $152-201$ & AB459399 \\
\hline Poli124TUF & Paralichthys olivaceus & $\begin{array}{l}\text { AGGAGCATGGCAATGTGAGACAC } \\
\text { GTACACTGTGAATCCAAGCCCAGTT }\end{array}$ & 62 & $94-110$ & AB459402 \\
\hline Poli129TUF & Paralichthys olivaceus & $\begin{array}{l}\text { TTGCTGACTTCCTCTGTTTACTCCC } \\
\text { ACAGCTGCTCTGTGTGTATGTTTGC }\end{array}$ & 62 & $82-112$ & AB459406 \\
\hline Poli136TUF & Paralichthys olivaceus & $\begin{array}{l}\text { CTGGTTGGAGTGGATGTAGGCTG } \\
\text { GTGAGACAGGTGCTGAGTCTTCTCC }\end{array}$ & 55 & $124-143$ & AB459411 \\
\hline Poli138TUF & Paralichthys olivaceus & $\begin{array}{l}\text { CCCGTCTTTAGTTTTTTCTTCTTGACC } \\
\text { CGGGAGGAAAGTCAGGTCATTAACT }\end{array}$ & 60 & $118-124$ & AB459412 \\
\hline Poli145TUF & Paralichthys olivaceus & $\begin{array}{l}\text { TGTTGCTCTGACACAGAGGAATGTC } \\
\text { GAATGTATTTCCCTGTTTGGCATGA }\end{array}$ & 60 & $122-149$ & AB459419 \\
\hline Poli149TUF & Paralichthys olivaceus & $\begin{array}{l}\text { CGTGTACAGTACACCTCCCAACAGA } \\
\text { GCTTGCGCCTGACAAACTGATATAA }\end{array}$ & 60 & $119-156$ & AB459423 \\
\hline Poli162TUF & Paralichthys olivaceus & $\begin{array}{l}\text { GTCCGTCAAATGGATTCAATGCTAA } \\
\text { CATGTCTCTGGACTTCACACAGGC }\end{array}$ & 55 & $96-128$ & AB459434 \\
\hline Poli163TUF & Paralichthys olivaceus & $\begin{array}{l}\text { ATCCACATCCCCTTTAGGCTAGTCC } \\
\text { ATGGCCTTGTGTTTGTTTCTGTTTG }\end{array}$ & 60 & $145-185$ & AB459435 \\
\hline Poli174TUF & Paralichthys olivaceus & $\begin{array}{l}\text { TAGAAACTGGCCTTCATGGTGTCTC } \\
\text { ATGTCAGAGTTTGAAAGCAGCAACC }\end{array}$ & 62 & $127-164$ & AB459445 \\
\hline Poli177TUF & Paralichthys olivaceus & $\begin{array}{l}\text { CTCGGCCTGTTTAATCTAATTTTTGC } \\
\text { AAGGTCACTGAGACATGAGAGGCAG }\end{array}$ & 60 & $121-138$ & AB459448 \\
\hline Poli183TUF & Paralichthys olivaceus & $\begin{array}{l}\text { CAAGGGCACCTTGTCTTAAAGGAAA } \\
\text { TTGATTGATAGTTTGACTGAGTCAGCA }\end{array}$ & 58 & $129-143$ & AB459454 \\
\hline Poli190TUF & Paralichthys olivaceus & $\begin{array}{l}\text { GAGTATACCCACTTCTCCAGGCACC } \\
\text { AAGAAACCAATCCACCGTTCACTG }\end{array}$ & 62 & $136-156$ & AB459460 \\
\hline Poli194TUF & Paralichthys olivaceus & $\begin{array}{l}\text { TGCAGCTGACTAATCCACTGCAG } \\
\text { AGTGTGTGTCTGTCCACTCTTGTGC }\end{array}$ & 65 & $126-143$ & AB459464 \\
\hline Poli198TUF & Paralichthys olivaceus & $\begin{array}{l}\text { TGGCAGTCTTATCAGCCTCTGCTAC } \\
\text { GGTGTCTGATGCTATCTCCACAGCT }\end{array}$ & 62 & $128-218$ & AB459467 \\
\hline Poli200TUF & Paralichthys olivaceus & $\begin{array}{l}\text { CTTGCTGACTTCCTCTGTTTACTCCC } \\
\text { ACAGCTGCTCTGTGTGTATGTTTGC }\end{array}$ & 62 & $83-113$ & AB086615 \\
\hline Poli9-8TUF & Paralichthys olivaceus & $\begin{array}{l}\text { GAGAGACAGAAGGTCGTCAACGGTA } \\
\text { ACAAAGACCACGATGCAAAGTGAC }\end{array}$ & 62 & $139-141$ & AB037989 \\
\hline Poli13-2TUF & Paralichthys olivaceus & $\begin{array}{l}\text { TCATCCCATTAAAGCATAGCG } \\
\text { ATCTCACAGCATCACTTGATGG }\end{array}$ & 60 & $95-123$ & AB459357 \\
\hline Poli16-24TUF & Paralichthys olivaceus & $\begin{array}{l}\text { GCCGTCAACACAGAACTGAG } \\
\text { TCTGAGAGATGATGACGCATC }\end{array}$ & 55 & $129-146$ & AB459363 \\
\hline Poli16-76TUF & Paralichthys olivaceus & $\begin{array}{l}\text { GCAGTGAGTGGACTTCAGGTGCTAT } \\
\text { TATAAGGTGGGAGAGAGGAAGGTGG }\end{array}$ & 65 & $99-105$ & AB459367 \\
\hline Poli18-42TUF & Paralichthys olivaceus & $\begin{array}{l}\text { GATCTCTGGAGGAGGAGGACGAC } \\
\text { CAGATAACATGCAGGTCACATCTGG }\end{array}$ & 55 & 144-169 & AB459373 \\
\hline Poli18-44TUF & Paralichthys olivaceus & $\begin{array}{l}\text { ATCCACTGAAGATAGTTTGGTTTGGG } \\
\text { CAGTCATCATGTTCCGAAACCATC }\end{array}$ & 55 & $129-148$ & AB459374 \\
\hline KOP3 & Paralichthys olivaceus & $\begin{array}{l}\text { AGAGGATATCGAGGGGAGG } \\
\text { CAGCAGTAGCCGATCTTAGTG }\end{array}$ & 65 & $114-116$ & AY328959 \\
\hline KOP18 & Paralichthys olivaceus & $\begin{array}{l}\text { GAAGGATCTGGACTCATGGTGAC } \\
\text { CAGCAGCAAAGGCAGAAAGAG }\end{array}$ & 67 & $199-237$ & AY328973 \\
\hline
\end{tabular}




\begin{tabular}{|c|c|c|c|c|c|}
\hline Locus & Source & Primer sequence $\left(5^{\prime} \rightarrow 3^{\prime}\right)$ & $\mathrm{Ta}\left({ }^{\circ} \mathrm{C}\right)$ & PCR size (bp) & Accession No. \\
\hline KOP19 & Paralichthys olivaceus & $\begin{array}{l}\text { TCCGGTTCAGGAGAGTTCAATG } \\
\text { GGTGGTTTGATCAGTCCATATG }\end{array}$ & 65 & $184-239$ & AY328974 \\
\hline KOP23 & Paralichthys olivaceus & $\begin{array}{l}\text { TCGATGAGTGTCCTCGCAACTA } \\
\text { ACCGCAGTCTGCAGTTCCTCT }\end{array}$ & 65 & $161-194$ & AY328978 \\
\hline KOP24 & Paralichthys olivaceus & $\begin{array}{l}\text { GCACGCTACCTGACTGAGAC } \\
\text { GGCTGGATTCTTCTGCTTC }\end{array}$ & 63 & $100-108$ & AY328979 \\
\hline KOP26 & Paralichthys olivaceus & $\begin{array}{l}\text { CAGTAAAACAGTCCCTCCTGAAC } \\
\text { GGAGTCTGGAACCAAATGTCTG }\end{array}$ & 60 & $181-201$ & AY328981 \\
\hline KOP32 & Paralichthys olivaceus & $\begin{array}{l}\text { TCAAACACTCATCCGTCTTC } \\
\text { GTTTCTCATGACTGGCTTGTAG }\end{array}$ & 60 & $183-197$ & EU307225 \\
\hline KOP44 & Paralichthys olivaceus & $\begin{array}{l}\text { GATTCTCAACGGCAGACCATT } \\
\text { GATCCCACCTTAAAAGTCAG }\end{array}$ & 56 & $206-214$ & EU307234 \\
\hline KOP46 & Paralichthys olivaceus & $\begin{array}{l}\text { AGAGTAACTACAGGAACTGCC } \\
\text { CAGTGCCCAACCTCTG }\end{array}$ & 56 & $140-160$ & EU307237 \\
\hline KOP57 & Paralichthys olivaceus & $\begin{array}{l}\text { GTTCATGTTTGACGGTCCTCG } \\
\text { GGGATTTGAAAGCGGGATTAGG }\end{array}$ & 56 & 209-215 & EU307247 \\
\hline KOP68 & Paralichthys olivaceus & $\begin{array}{l}\text { AGGTCAGGGTCACTCGTG } \\
\text { TGACAAGAGGAATCATCACAA }\end{array}$ & 56 & $131-134$ & EU307254 \\
\hline Poli5MHFS & Paralichthys olivaceus & $\begin{array}{l}\text { AAAGCAGAAGGGTCAAGC } \\
\text { CAAAGATCGAGGGTCAGC }\end{array}$ & 60 & $110-139$ & AB459314 \\
\hline Poli12MHFS & Paralichthys olivaceus & $\begin{array}{l}\text { CAGTGCCTAAACCAGTGT } \\
\text { TGTGCTACCGTGAATAAT }\end{array}$ & 60 & $165-205$ & AB459319 \\
\hline Poli14MHFS & Paralichthys olivaceus & $\begin{array}{l}\text { CCAGCCAAAACAAAACCATA } \\
\text { AATAACAAAGAACGGACAGC }\end{array}$ & 60 & $113-178$ & AB459321 \\
\hline Poli31MHFS & Paralichthys olivaceus & $\begin{array}{l}\text { GGAGAGTTTGCTGAGTCAAC } \\
\text { TGTAAGCTGAGGAAAGAAAT }\end{array}$ & 60 & $115-135$ & AB459329 \\
\hline Poli32MHFS & Paralichthys olivaceus & $\begin{array}{l}\text { GCTGGGTTGGTGGGAGTTATGG } \\
\text { AAGGTTAGGTTACGGTTAGACA }\end{array}$ & 60 & $134-155$ & AB459330 \\
\hline Poli38MHFS & Paralichthys olivaceus & $\begin{array}{l}\text { CAGTTGAAGGGAGTGATGTC } \\
\text { GGAAGGAAATAGTTAGAGTG }\end{array}$ & 60 & $183-260$ & AB459332 \\
\hline Poli39MHFS & Paralichthys olivaceus & $\begin{array}{l}\text { GGCCTTGTTGTTGTCTGTGA } \\
\text { ACCGAATGTGAATCTGAAAA }\end{array}$ & 60 & $167-189$ & AB459333 \\
\hline Poli66MHFS & Paralichthys olivaceus & $\begin{array}{l}\text { TCTACCAAACTCTCAATCCT } \\
\text { TCACTTCACTTATCCCACAG }\end{array}$ & 60 & $194-207$ & AB459335 \\
\hline Poli92MHFS & Paralichthys olivaceus & $\begin{array}{l}\text { ATCACTGTTTCATTAGGG } \\
\text { CTGGACGCATTCTTTGTA }\end{array}$ & 60 & $106-133$ & AB459341 \\
\hline Ksf1 & Platichthys stellatus & $\begin{array}{l}\text { CGCCACATAATAACAGCA } \\
\text { AAGACATGACTGGGAGAA }\end{array}$ & 54 & $221-229$ & JF913209 \\
\hline Ksf13 & Platichthys stellatus & $\begin{array}{l}\text { AGAAGAGCTCTGTGACTC } \\
\text { GAGACACACTGACAAACC }\end{array}$ & 54 & $133-169$ & JF913221 \\
\hline Ksf14 & Platichthys stellatus & $\begin{array}{l}\text { ACAGCAGCCGATAACATGAG } \\
\text { CGTCCCCTTATGATGAGACAAC }\end{array}$ & 58 & $233-275$ & JF913222 \\
\hline Ksf15 & Platichthys stellatus & $\begin{array}{l}\text { GGAAGAGACAGTTCACCA } \\
\text { CTCAGCAGTCTTCAAACC }\end{array}$ & 54 & $251-263$ & JF913223 \\
\hline Ksf25 & Platichthys stellatus & $\begin{array}{l}\text { GCCTCTTAGGTAAGACATGCGA } \\
\text { GCTGTCACCCTGTTCAACCA }\end{array}$ & 58 & $129-137$ & JF913233 \\
\hline Ksf26 & Platichthys stellatus & $\begin{array}{l}\text { CAGGGACATGAAAAGGTTG } \\
\text { GAGCATGTCAGAAAGATGG }\end{array}$ & 56 & $129-137$ & JF913234 \\
\hline Ksf29 & Platichthys stellatus & $\begin{array}{l}\text { GAGACTCAGATCGCAGTCCA } \\
\text { CCCCTGAGATCAAGGGTGTT }\end{array}$ & 58 & $138-148$ & JF913237 \\
\hline Ksf33 & Platichthys stellatus & $\begin{array}{l}\text { CAGGCAGATGTCTATGGGATGA } \\
\text { CTTACCGAATGGGACAGCAAAC }\end{array}$ & 56 & $188-198$ & JF913241 \\
\hline Ksf35 & Platichthys stellatus & $\begin{array}{l}\text { GCAATGAAACGTGTTCTG } \\
\text { GGCTGTGTTGATGATCTC }\end{array}$ & 54 & $104-140$ & JF913243 \\
\hline Ksf46 & Platichthys stellatus & $\begin{array}{l}\text { CCTGCGTTTGACTTCAACTG } \\
\text { AACCACAGAAGCTGTTCTCC }\end{array}$ & 58 & $156-258$ & JF913254 \\
\hline Ksf47 & Platichthys stellatus & $\begin{array}{l}\text { ATGCAACAGCTCCGAGGCAA } \\
\text { GCTGACGTGAAGACTGGGACAA }\end{array}$ & 58 & $132-176$ & JF913255 \\
\hline Ksf54 & Platichthys stellatus & $\begin{array}{l}\text { AGACGGTTCACTCTGAAG } \\
\text { GTAGCCGTACAAACATGG }\end{array}$ & 54 & $208-216$ & JF913262 \\
\hline Ksf55 & Platichthys stellatus & $\begin{array}{l}\text { AAGCCCTCATTCTTCGAAGCTC } \\
\text { AATAAGGAGCCGGTGCTCAA }\end{array}$ & 58 & $236-248$ & JF913263 \\
\hline
\end{tabular}

$\mathrm{Ta}=$ annealing temperature; $\mathrm{PCR}=$ polymerase chain reaction. 


\section{Identification and parentage confirmation of hybrids}

Multiplex PCR using two primer sets that are specific to each species and produce PCR products of different sizes could be used for the identification of hybrids. For example, the primer set for the olive flounder-specific Kop60 marker and starry flounder-specific Ksf5 marker produced corresponding PCR products in each parent and two PCR products from the hybrid of the two species (Figure 1).

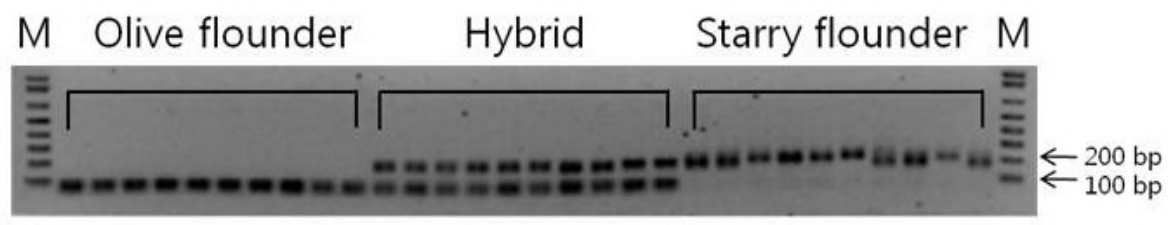

Figure 1. Amplification profile of olive flounder, starry flounder and their hybrid in multiplex PCR with primer sets for olive flounder-specific Kop 60 and starry flounder-specific Ksf5 markers.

In contrast, the primer set for the markers common to two species could be used for the analysis of genetic inheritance. Among the 62 microsatellite markers common to both species, seven markers (Kop24, Kop68, Poli108TUF, Poli11TUF, Poli172TUF, Poli13-2TUF, and Poli131TUF) showing polymorphism in the parent genotype were selected for genetic inheritance analysis. The inheritance of each microsatellite in the interfamily hybrids was analyzed, and two examples shown in Figure 2 demonstrate classic Mendelian inheritance of the markers in the hybrid progeny. Table 2 shows the genotype of the female olive flounder and male starry flounder, the expected separation of genotype, and observed genotype ratio in the hybrid. The genotype analysis showed a typical Mendelian ratio of 1:1:1:1 at most loci with the exception of the Poil72TUF locus.

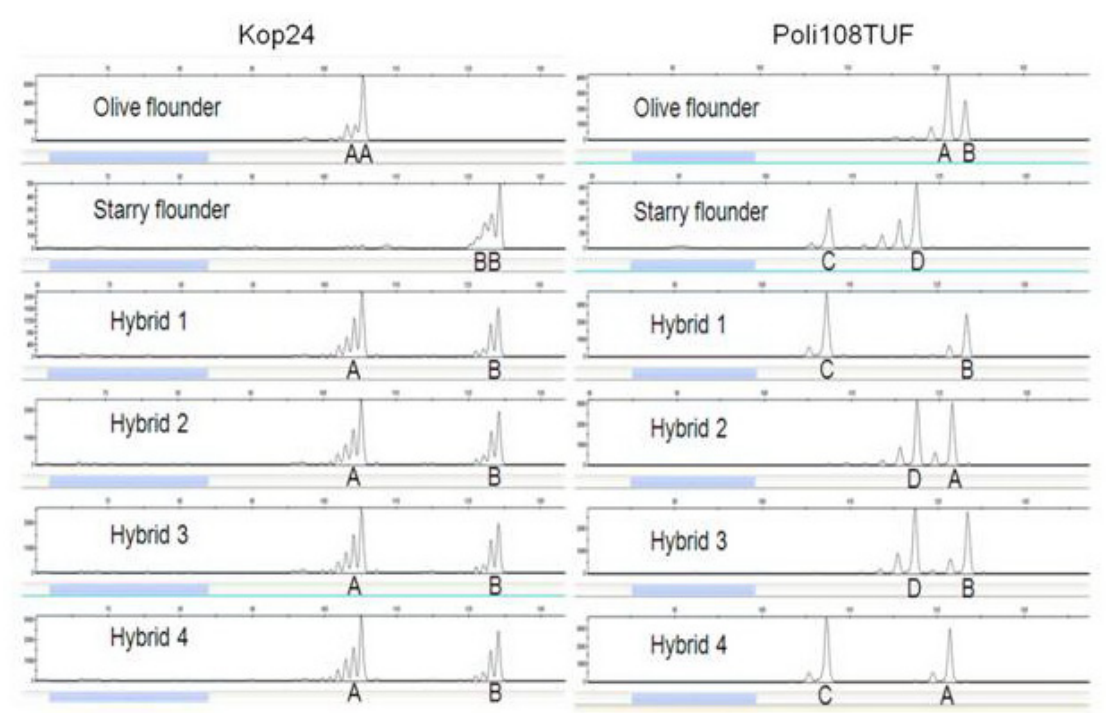

Figure 2. Genotyping of parental olive flounder, starry flounder and their hybrid using microsatellite markers Kop24 and Poli108TUF, which are common to both species. 


\begin{tabular}{|c|c|c|c|c|c|}
\hline \multirow[t]{2}{*}{ Marker locus } & \multicolumn{2}{|c|}{ Parent genotype } & \multicolumn{2}{|c|}{ Hybrid genotype } & \multirow[t]{2}{*}{$P$ value } \\
\hline & Olive flounder & Starry flounder & Expected pattern & Observed ratio & \\
\hline Кор 24 & AA (110/110) & BB (129/129) & $\mathrm{AB}$ & 48 & 1 \\
\hline Poli108TUF & $\mathrm{AB}(126 / 128)$ & $\mathrm{CD}(112 / 122)$ & AC:AD:BC:BD & 15:13:9:11 & 0.644 \\
\hline Кор68 & AB (132/134) & CC (144/144) & $\mathrm{AC}: \mathrm{BC}$ & $25: 23$ & 0.773 \\
\hline Poli11TUF & $\mathrm{AB}(111 / 117)$ & CC (105/105) & $\mathrm{AC}: \mathrm{BC}$ & $28: 20$ & 0.248 \\
\hline Poli172TUF & $\mathrm{AA}(123 / 123)$ & BB (113/113) & $\mathrm{AB}$ & $0(\mathrm{AA}=48)$ & 0 \\
\hline Poli13-2TUF & $\mathrm{AB}(96 / 98)$ & CC (112/112) & $\mathrm{AC}: \mathrm{BC}$ & $25: 23$ & 0.773 \\
\hline Poli131TUF & AA $(107 / 107)$ & BC (101/103) & $\mathrm{AB}: \mathrm{AC}$ & $22: 26$ & 0.564 \\
\hline
\end{tabular}

\section{DISCUSSION}

Heterosis resulting from crosses between different species shows phenotypic superiority of a hybrid over its parents with respect to traits such as growth rate, reproductive success, and yield, probably by some non-mutually exclusive mechanisms such as dominance complementation, overdominance, and epistasis (Duvick, 1999). Although hybridization is a new technique in aquaculture compared to animal husbandry and agriculture, several biological characteristics of fish, such as high fecundity, external fertilization, and relative simplicity of obtaining viable and fertile hybrids, have promoted the hybridization of aquaculture fish. Hybrids have been successfully produced and commercially used in sturgeon, white fish, tilapia, catfish, and various cyprinids (Bartley et al., 2000).

One interesting feature in the production of the hybrid between $P$. olivaceus and $P$. stellatus is that they belong to different families of the order Pleuronectiformes; P. olivaceus belongs to the family Paralichthyidae, and P. stellatus belongs to the Pleuronectidae. Although hybrid fish have been produced by bigeneric crossing, such as between the two sturgeons Huso huso and Acipenser ruthenus and between silver carp (Hypophthalmichthys molitrix) and bighead carp (Aristichthys nobilis), most hybrid fish that have been developed to date are intraspecific or interspecific (Bartley et al., 2000). Although P. olivaceus and P. stellatus belong to different families, sequence analysis of the mitochondrial 16S rDNA showed that these two families are very close to each other on the phylogenetic tree, which could explain the feasibility of hybrid production (Pardo et al., 2005; Azevedo et al., 2008). The hybrid between the female $P$. olivaceus and male $P$. stellatus showed more morphological similarity to $P$. stellatus; growth was improved, but the hybrid was not fertile (Nam et al., 2008).

Accurate identification and screening of hybrids is very important in breeding programs and in the analysis of hybrid invasion in natural environments, which is time-consuming and difficult in some species. Molecular markers, such as RAPD markers and microsatellite markers, have been used for the identification of hybrids in plants (Asif et al., 2009; Conceição et al., 2011) and fish (Wenburg et al., 1998). One limitation in the application of microsatellite markers for hybrid identification is an overlapping allele size. In our study, we used species-specific primer sets for identifying the hybrid by multiplex PCR. In addition to the species-specific fixed markers of different sizes, a primer set common to both parents but that produced allele products of different size ranges in different parents, could be used for both hybrid identification and inheritance analysis.

Microsatellite markers can be developed by many methods, for example, comparing 
massive sequences such as the EST sequence, cloning random segments of DNA from the focal species followed by screening with fluorescent-labeled oligonucleotide sequences that will hybridize to a microsatellite repeat, or by enrichment of the microsatellite with oligonucleotides complementary to repeats (Kaukinen et al., 2004). Despite these advances, the development of correctly functioning primers is often a tedious and costly process. One way to solve this problem is to apply microsatellite markers developed for a particular species to closely related species. Liu et al. (1999) showed that 29 of 32 primer sets designed from channel catfish (Ictalurus punctatus) successfully amplified genomic DNA from blue catfish (I. furcatus). They also showed that 14 of them amplified genomic DNA from flathead catfish (Pylodictis olivaris) and 13 amplified microsatellites in white catfish (Ameiurus catus), which suggests the possible construction of a unified catfish map using conserved polymorphic markers. Wu et al. (1999) also demonstrated that polymorphic microsatellite markers could be amplified from different species of cichlid fish belonging to the same family (Cichlidae). However, the percentage of loci that successfully amplify may decrease with increasing genetic distance (Jarne and Lagoda, 1996). For example, among 64 microsatellite markers derived from olive flounder, $16(25.0 \%)$ and $17(26.5 \%)$ could amplify the corresponding DNA fragment from barfin flounder (Verasper moseri) and spotted halilbut (Verasper variegatus), respectively (Ma and Chen, 2011). In our experiment, 49 (25.5\%) of 192 markers derived from olive flounder successfully amplified DNA fragments from $P$. stellatus. Considering that $P$. stellatus belongs to the same family (Paralichthyidae) of the order Pleuronectiformes, the value is higher than that of the previous results, probably because more markers derived from olive flounder were used. In fact, 13 (23.2\%) of the 56 markers derived from starry flounder amplified the target DNA from olive flounder; this percentage is very close to that of Ma and Chen (2011).

In addition to the search for microsatellite markers that can undergo cross-species amplification of polymorphic DNA fragments, selected markers were used to analyze Mendelian inheritance of genotypes in the hybrid of two species. Among the seven microsatellite markers used, six showed Mendelian inheritance, suggesting that cross-specific microsatellite markers are useful tools for the parentage analysis of hybrid organisms.

Many useful characteristics, such as rapid growth and resistance to disease and environmental stresses, tended to be quantitative traits, and the availability of conserved microsatellite markers will be helpful in mapping those quantitative trait loci, marker-assisted selective breeding, and understanding the evolution of aquatic organisms.

\section{ACKNOWLEDGMENTS}

Research supported by the National Fisheries Research and Development Institute (NFRDI) in Korea (\#RP-2011-BT-45).

\section{REFERENCES}

Asif M, Mehboob-Ur-Rahman, Miraza JI and Zafar Y (2009). Parentage confirmation of cotton hybrids using molecular markers. Pak. J. Bot. 41: 695-701.

Azevedo MFC, Oliveira C, Pardo BG and Martínez P (2008). Phylogenetic analysis of the order Pleuronectiformes (Teleostei) based on sequences of 12S and 16S mitochondrial genes. Genet. Mol. Biol. 31: 284-292.

Bartley DM, Rana K and Immink A (2000). The use of interspecific hybrids in aquaculture and fisheries. Rev. Fish Biol. Fish. 10: 325-337. 
Berrebi P, Povz M, Jesensek D and Cattaneo-Berrebi G (2000). The genetic diversity of native, stocked and hybrid populations of marble trout in the Soca river, Slovenia. Heredity 85: 277-287.

Conceição LD, Belo GO, Souza MM, Santos SF, et al. (2011). Confirmation of cross-fertilization using molecular markers in ornamental passion flower hybrids. Genet. Mol. Res. 10: 47-52.

Duvick DN (1999). Heterosis: Feeding People and Protecting Natural Resources. In: The Genetics and Exploitation of Heterosis in Crops (Coors JG and Pandey S, eds.). American Society of Agronomy, Crop Science Society of America, and Soil Science Society of America, Madison, 19-29.

Fumagalli L, Snoj A, Jesensek D, Balloux F, et al. (2002). Extreme genetic differentiation among the remnant populations of marble trout (Salmo marmoratus) in Slovenia. Mol. Ecol. 11: 2711-2716.

Harwood AS and Phillips RB (2011). A suite of twelve single nucleotide polymorphism markers for detecting introgression between cutthroat and rainbow trout. Mol. Ecol. Res. 11: 382-385.

Ihssen PE, Casselman JM, Martin GW and Philips RB (1988). Biochemical genetics differentiation of lake trout (Salvelinus namaycush) stocks of the Great Lakes region. Can. J. Fish. Aquat. Sci. 45: 1018-1029.

Jarne P and Lagoda PJ (1996). Microsatellites, from molecules to populations and back. Trends Ecol. Evol. 11: 424-429.

Jug T, Dove P, Pohar J and Snoj A (2004). RAPD analysis as a tool for discriminating marble trout from hybrids (marble trout $\mathrm{x}$ brown trout) in the zones of hybridization. J. Anim. Breed. Genet. 121: 156-162.

Kang JH, Kim WJ and Lee WJ (2008). Genetic linkage map of olive flounder, Paralichthys olivaceus. Int. J. Biol. Sci. 4: 143-149.

Kaukinen KH, Supernault KJ and Miller KM (2004). Enrichment of tetranucleotide microsatellite loci from invertebrate species. J. Shellfish Res. 23: 621.

Leary RF, Allendorf FW and Sage GK (1995). Hybridization and introgression between introduced and native fish. Am. Fish Soc. Symp. 15: 91-101.

Li YC, Korol AB, Fahima T and Nevo E (2004). Microsatellites within genes: structure, function and evolution. Mol. Biol. Evol. 21: 991-1007.

Liu Z, Tan G, Kucuktas H and Li P (1999). High levels of conservation at microsatellite loci among Ictalurid catfishes. $J$. Hered. 90: 307-312.

Ma H and Chen S (2011). Development of polymorphic microsatellite markers in barfin flounder (Verasper moseri) and spotted halibut (Verasper variegatus) by the cross-species amplification. Mol. Biol. Rep. 38: 4545-4551.

Moav R (1979). Genetic Improvement in Aquaculture Industry. In: Advances in Aquaculture (Pillay TVR and Dill WA, eds.). Fishing News Books Ltd., Farnham, Surrey, 610-622.

Nam MM, Byun SG, Lee BI and Lee JH (2008). Morphological characteristics of the hybrids of female flounder Paralichthys olivaceus and male starry flounder Platichthys stellatus. Kor. J. Ichthyol. 20: 285-290.

Pardo BG, Machordom A, Foresti F and Porto-Foresti F (2005). Phylogenetic analysis of flatfishes (Order Pleuronectiformes) based on mitochondrial 16s rDNA sequences. Sci. Mar. 69: 531-543.

Snoj A, Jug T, Melkic E and Susnik S (2000). Mitochondrial and microsatellite DNA analysis of marble trout in Slovenia. Quaderni ETP 29: 5-11.

Wenburg JK, Bentzen P and Foote CJ (1998). Microsatellite analysis of genetic population structure in an endangered salmonid: the coastal cutthroat trout (Oncorhynchus clarki clarki). Mol. Ecol. 7: 733-749.

Wohlfarth GW (1993). Heterosis for growth rate in common carp. Aquaculture 113: 31-46.

Wu L, Kaufman L and Fuerst PA (1999). Isolation of microsatellite markers in Astatoreochromis alluaudi and their crossspecies amplifications in other African cichlids. Mol. Ecol. 8: 895-897. 